Studia Anglica Posnaniensia 46/3, 2011(2010)

doi: 10.2478/v10121-010-0007-4

\title{
LOCUS AMOENUS OR LOCUS HORRIDUS: THE FOREST OF ARDEN AS A SETTING IN AS YOU LIKE IT
}

\author{
SYLWIA WOJCIECHOWSKA
}

Nicolaus Copernicus University, Toruń

\begin{abstract}
As you like it stands out from the rest of Shakespeare's plays as a comedy of conspicuously unusual dramaturgy. Critics have vindicated its idiosyncratic form claiming that As you like it's uneventful plot is due to the pastoral character of the play. Along with such typically pastoral elements as song contests or lover's woes they have listed its setting as an example of an idyllic locus amoenus. This article examines the actual character of the Forest of Arden and turns readers' attention towards the equivocal image of the place.
\end{abstract}

Despite Shakespeare's canonical status, As you like it ${ }^{1}$ has met with a mixed reception among critics: some have been enthusiastic about the comedy, others quite the opposite (Alpers 1996: 70ff). Admittedly, AYLI stands out among other plays by the most famous Elizabethan dramatist. On the one hand, it proves Shakespeare a literary virtuoso as the play is a good example of a successfully created generic amalgam: the comedy embraces elements of pastoral and satire as well as romance and parody. ${ }^{2}$ On the other hand, however, it "comes nearer in form to a discussion play or a symposium than any other of Shakespeare's comedies" (Salingar 1974: 293). This idiosyncratic frame of the drama is not unanimously reckoned as its advantage, though, the blame being the alleged lack of a lively developing action and a proper conclusion. ${ }^{3}$ Yet, the

\footnotetext{
Henceforth, As you like it will be referred to as AYLI (The Arden Edition, 2001).

Shakespeare was acutely aware of the possibilities open to a playwright as far as a generic fusion is concerned -cf. Polonius' catalog of various literary subgenres in Hamlet 2.2. 392-395.

3 "This play $[A Y L I]$ is a uniquely powerful way of presenting the richness and complexity of a relationship; but it requires a suspension of place, time and intrigue, and this becalming of the
} 
often suspended course of events is explicable by the fact that the leading mode of the comedy is pastoral.

It comes as no surprise that the pastoral mode exerted such an impact on the dramatic frame of $A Y L I$. Dated $1600,{ }^{4}$ the comedy was composed at a time when "pastoral suddenly turned into fashion - almost a craze ..." (Cooper 1977: 144). ${ }^{5}$ Dismissed as worthless, ${ }^{6}$ the existence of a plethora of Renaissance pastorals confirms the force of attraction the Elizabethans felt for the pastoral genre. Composing the play, Shakespeare drew inspiration from Thomas Lodge's pastoral romance, Rosalynde, ${ }^{7}$ which must have influenced the plot of $A Y L I$. Coming up to the expectations of his audience, the playwright wrote a comedy whose leading mode is pastoral.

Admittedly, AYLI meets the requirements of the genre in many respects. Not only are the names telling (Phebe, for example, adopted from Lodge's romance, is a traditionally pastoral name ${ }^{8}$ ) as well as the setting. It is, however, much more than these features that renders the play idyllic; namely, the pastoral pattern on which the comedy is founded. This holds true for the thematic consistency, the main theme under discussion being love experienced in an idyllic place and contrasted with amorality on court. Yet, what mainly contributes to the idiosyncrasies of $A Y L I$ is the dramatic texture often taking the form of an 'agon' (Gr. $\alpha \dot{\gamma} \omega \dot{\omega} v$ 'song contest'), ${ }^{9}$ a means traditionally inherent in pastoral and adopted by Shakespeare, at times translated into a wit contest. ${ }^{10}$

As mentioned above, among typically pastoral elements in $A Y L I$, one finds the idyllic setting: the Forest of Arden. By convention, such a locale is called locus amoenus, "a set-piece description of an ideal landscape which often forms

play makes it difficult to steer it to a satisfactory conclusion" (Hunter 1962: 39).

Concerning the means of the masque employed in the denouement of $A Y L I$ see the Introduction to $A Y L I$ (2001: xxi ff).

4 More information in the Introduction to $A Y L I$ (2001: xxvi ff).

5 Concerning the interest in the pastoral in the Renaissance see also Alpers (1996) and Smith (1966: 62).

Regarding the development of Renaissance pastoral in England and on the Continent see Chaudhuri (1989: 156).

6 Concerning various literary value of Elizabethan pastorals confer, for example, a Renaissance collection entitled England's Helicon (1962), edited by Hugh MacDonald.

7 Within fifty years, that had passed from its first edition, there were nine editions of Rosalynde which testifies to the wide appeal of pastoral witnessed in England on the turn of the $16^{\text {th }}$ century (cf. the Introduction to $A Y L I$ 2001: xxxv).

8 (Introduction to AYLI 2001: lxvi. The same concerns the etymology of Corin's name.

9 The means was first applied in Idylls by Theocritus; cf. for example, Idyll I. Compare the song "Under a Greenwood Tree" in AYLI 2.5.

10 Pastoral drama is acknowledged to have its roots in Virgil's Eclogues, originally composed as dialogues, be they singing contests or not. Consequently, “... pastoral dramas are episodic, characterized by set pieces, relatively unmarked by the shapings and energies of plot" (Alpers 1996: 70). The same is true for $A Y L I$. 
the backdrop for romantic encounters" (Loughrey 1984: 25). ${ }^{11}$ The Latin phrase $^{12}$ is not testified to in Virgilian Eclogues, ${ }^{13}$ though. Nonetheless, it appears in another influential piece of pastoral literature, namely in L'Arcadia by Jacopo Sannazaro (1504). ${ }^{14}$ Its first chapter, prosa prima, "[gives a description of a place of meeting in a locus amoenus on Mount Parthenios where goatherds take part in singing contests and other games]". ${ }^{15}$ Following the example of Virgil, Sannazaro locates his locus amoenus in Arcadia, a region associated with a really existing part of Greece. ${ }^{16}$ In contradistinction, however, right from the beginning he focuses on the landscape and starts the very first chapter, prosa prima, with the words: ["At the peak of Mount Parthenios, no small mountain of the pastoral Arcadia, there is a delightful plain..."]. ${ }^{17}$ Then he gives

11 Stownik terminów literackich [The glossary of literary terms] defines locus amoenus as follows: "jeden z najczęściej występujących toposów piśmiennictwa z kręgu kultury śródziemnomorskiej: lit. przedstawienie miejsca miłego, jasnego, dającego człowiekowi odpoczynek fizyczny i spokój duchowy; najczęściej jest to obraz przyjaznej przyrody" [one of the most common literary topoi in the Mediterranean culture: it is a literary representation of a sunny and lovely place providing physical rest and tranquillity; most often it is a picture of friendly nature] (Głowiński et al. 1998: 287), s.v. locus amoenus.

12 It is a combination of two Latin words: locus, 'a place', and amoenus, 'lovely'. Interestingly enough, although locus has a mainly spatial connotation (a place of a given topography), the word also has a temporal meaning: locus as a certain moment in time (cf. Stownik łacińskopolski [Polish-Latin Dictionary] (Plezia 1998, III: 379f); s.v. locus, II B. This seems to prove the interdependence between the concept of the locus amoenus and the spatial and temporal versions of Arcadia.

13 This is striking because Virgil, along with Theocritus, is widely acknowledged as the father of the pastoral. Still, even if the phrase is not present in his Eclogues, their locale is "lovely" (cf. for example, the song of Damon in Ecl. VIII).

14 L'Arcadia by Sannazaro influenced Renaissance poets all over Europe: “Jorge de Montemayor, portoghese di nascita, Michele Cervantes, spagnuolo, Onorato d'Hurfè, francese, Philip Spenser, inglese, sono altrettanti continuatori della geniale opera del Sannazaro" [Jorge de Montemayor, Portuguese by descent, Michele Cervantes, a Spanish, Onorato d'Hurfè, a Frenchman, Philip Spenser, an Englishman, they all continued Sannazaro's brilliant work] (Introduction to L'Arcadia, Carrara 1948: xxxii).

15 "Si descrive un ameno luogo [emphasis mine, SW] di convegno sul Partenio ove i pastori fanno gare di giuochi e canti. Quivi Selvaggio vedendo Ergasto giacere muto e triste lo provoca al canto" (Sannazaro 1948: 167).

The adjective ameno is used in the text of L'Arcadia as well: lo amenissimo platano 'the most lovely plane tree'.

16 Theocritus' locus amoenus featured Sicily. Virgil, on the other hand, transferred it to Arcadia; misleadingly enough, adopting the name of the Pelopennesian region he did not mean to depict it in close detail since "Arkadien war da nichts als ein wenig auffallendes: Weide und Bergland im Peleponnes" [there was nothing special about the country: meadows and mountains on the Peloponnesian peninsula] (Bloch 1976: 3). See Bloch (1976) for more information about Virgil's Arcadia.

17 "Giace ne la sommità di Partenio, non umile monte de la pastorale Arcadia [emphasis mine, SW], un dilettevole piano.." (Sannazaro 1948: 5). 
free rein to his vivid imagination depicting the deep green of the grass, ${ }^{18}$ the variety of trees, ${ }^{19}$ peaceful flocks of sheep and ["the natural beauty of the site"]. ${ }^{20}$

This landscape description became very influential in the Renaissance Europe. It embraced basic topographical details of the locus amoenus and constituted a starting point for pastoral place descriptions. ${ }^{21}$ It was a point of reference for both the pastoral writers and their public. The same holds true for Shakespeare and his audience.

Interestingly enough, $A Y L I$ starts outside the locus amoenus, partly "here in your [Oliver's] orchard"22 (1.1.41), partly at Duke Frederick's court. It is only in Act II that the place of action changes and the audience alongside the dramatis personae are admitted into the confines of the Forest of Arden. On the dramatic plane, such a shift of the locale is desirable as it helps to visualise the core tensions within the play. As far as the generic status of $A Y L I$ is concerned, the shift even gains in importance because right from the beginning basic pastoral contrasts are laid down: the discord between the rich and sophisticated, traditionally represented by the city (here it is the court), and the poor and unrefined, symbolised by the country (the forest, in this case) ${ }^{23}$ Thus, Shakespeare traditionally presents the court as a place where neither virtue nor old age is held in esteem. Rosalynd is expelled from court only because, as a virtuous lady, "[she] robs thee [Celia] of thy name" (1.3.76). Adam expresses his bitter disappointment at Oliver's ill-treatment by asking a question which he answers himself: "Is old dog my reward? Most true, I have lost my teeth in your service." (1.1.82-83). Such amorality exemplified in Act 1 stands in sharp contrast to the image of the Forest of Arden sketched in Act 1 and depicted with close scrutiny further on.

18 For the most part, the adjectives in the original description are used in their superlative form which is meant to emphasise the outstanding beauty of the described objects, e.g., verdissima erbetta [lit. 'the greenest grass'].

19 ...son forse dodici o quindici alberi [there are some twelve or fifteen trees] among which he enumerates il drittissimo abete 'straight fir tree', la robusta quercia 'robust oak tree', lo amenissimo platano 'lovely plane tree', l'albero, di che Ercule coronar si solea 'Hercules' tree', i.e. poplar tree [my specification, SW], il noderoso castagno 'rugged chestnut tree', lo ombroso faggio 'shadowy beech tree', la incorruttibile tiglia 'unyielding lime tree', 'l fragile tamarisco 'delicate tamarisk tree', un dritto cipresso 'straight cypress' and la orientale palma 'oriental palm tree'. Almost every adjective is used in its superlative form.

20 La naturale bellezza del luogo expresses the core pastoral opposition: art versus nature.

21 It was for the first time in the history of the pastoral that pastoral speakers "si sperdevano in uno sfondo senza paesaggio" [no longer roamed around a place lacking actual landscape traits] (Introduction to Sannazaro 1948: xxiii).

22 Admittedly, an orchard is an example of natural setting; yet, it is often regarded as the epitome of nature constrained by man and therefore associated with anti-pastoral space.

23 More information on pastoral contrasts (city vs. country, natural vs. artificial, innocence vs. experience, etc.) is given in Alpers (1996). 
As mentioned above, the Forest of Arden is referred to as early as Act 1, Scene 1. It is striking how skillfully Shakespeare discloses the details of the place of Duke's Senior banishment. First, the audience are acquainted with the circumstances of his leaving:

... the old Duke is banished by his younger brother the new Duke, and three or four loving lords have put themselves into voluntary exile [emphasis mine, SW] with him, whose lands and revenues enrich the new Duke, therefore he gives them good leave to wander (1.1.99-104).

Interestingly enough, right from the start spectators associate the place positively because of the adjective "voluntary" assigned to the "exile". A few lines later they get to know the locale in closer detail:

\begin{abstract}
They say he is already in the Forest of Arden, and a many merry men with him; and there they live like the old Robin Hood of England. They say many young gentlemen flock to him every day, and fleet the time carelessly as they did in the golden world (1.1.114-119) [all emphases are mine, SW].
\end{abstract}

This passage embraces a fairly pastoral image even if it is not clear if the audience are expected to have in mind the English or the European countryside. The problem lies in the fact that, on the one hand, Shakespeare might have alluded to some parts of Warwickshire known as Arden; ${ }^{24}$ on the other hand, however, he might have had in mind the region of European Ardennes traditionally assigned romantic features. ${ }^{25}$ Whatever the associations, one thing is fact undeniable: the Forest of Arden is in the play a locus amoenus. By convention, remote from the sophisticated centre, Duke Frederick's court, the forest offers the fugitives a shelter where they can live in the open enjoying the new, "carefree" way of life. This is why Duke Senior is surrounded by "many merry men" whose number is on the constant increase. Interestingly enough, the first description of the locale suggests that it unites characteristics of both spatial and temporal Arcadia. ${ }^{26}$ The overt reference to spatial Arcadia, a faraway place nonetheless remaining within the exiles' reach and offering them a long-sought-for retreat, is no surprise in $A Y L I$. Yet, the last words of the quotation impart an additional reading to the passage: "the golden world" vision. They impose traditional features of temporal Arcadia on spatial Arcadia: the nostalgic image of a world irrevocably lost to humanity. ${ }^{27}$ These two, to some extent contradictory versions of Arcadia seem united in the very first sketch of Shakespearean locus amoenus.

24 “... though no forest of that name survived" (AYLI 2001: 8, n.114).

25 Ardennes lies on the border of Luxembourg and Belgium; it is mentioned in Orlando furioso by Ariosto and in Astrophel by Spenser.

26 More information on spatial and temporal Arcadia in Snyder (1998: 3).

27 Both the motifs, the Golden Age and Garden of Eden, exemplify temporal Arcadia. More information in Marinelli (1971: 15f). 
There is, however, one unconventional feature added to the pastoral image of the Forest of Arden, namely, Duke is compared to "the old Robin Hood of England". Admittedly, the figure is well known from the English national lore, ${ }^{28}$ but it is unrelated to the tradition of the pastoral. Introducing such a novelty, Shakespeare followed in the footsteps of Virgil; the Roman poet had transformed Theocritean vision of Sicilian Arcadia ${ }^{29}$ into a landscape of partly Italian, partly Greek characteristics. ${ }^{30}$

In Act 2, Scene 1 more details are added and the image of the place becomes manifest. On the one hand, Duke Senior praises the place of banishment by posing rhetorical questions that juxtapose the forest and the court: "Hath not old custom made this life more sweet/ Than that of painted pomp? Are not these woods/ More free from peril than the envious court?/ Here feel we not the penalty of Adam" (2.1.2-5) [emphases mine, SW]. The passage conforms to the pastoral convention. It underlines the marked contrast between "the envious court" with its "painted pomp" and flattery and the undisturbed freedom from vice experienced in "these woods". The life in the forest is conventionally described as "sweet", an adjective inseparably bound up with the pastoral tradition. ${ }^{31}$ Moreover, the exiles enjoy a life of prelapsarian ease living the way our forefathers used to live in the Garden of Eden, namely, in a perfect harmony with nature supplying them with anything they needed. Bearing these characteristics in mind, the audience are startled to hear Duke Senior asking: "Come, shall we go and kill us venison?" (2.1.21). Not only does such a question stand in a sharp contrast to the Edenic remembrances but it also strikes a discordant note in a comedy whose leading mode is pastoral. It must not be forgotten that the pastoral world presupposes its inhabitants living in harmony with each other, be they people or animals. ${ }^{32} \mathrm{Nei}-$ ther do people kill animals nor do they have to because nature voluntarily provides them with everything they need. If it is not the case in $A Y L I$ the Forest of

28 “... it represented a version of the green world which was simultaneously politicised and idealised" (Mangan 1996: 204).

Robin Hood's legend was often employed in Elizabethan dramas (cf. Gibińska et al. 2003: 92).

29 Sicily was the country of Theocritus' childhood and it became the locus amoenus in his pastoral Idylls (cf. Marinelli 1971: 39f).

30 Concerning the displacement of Arcadia cf. Marinelli (1971: 39f). See also a seminal study on Virgilian Arcadia by Snell (1976).

31 Its literary history starts with Theocritus' Idylls (Gk. ó $\delta$ '́, 'sweet'-cf. Idyll I,1) and Virgil's Eclogues (Lat. dulcis 'sweet'; cf. dulcia arva in Ecl. I,3) and it was translated into English as 'sweet'. The adjective traditionally described the locus amoenus (cf. Schmidt 1972: 28ff). In $A Y L I$ the adjective is repeated (cf., e.g. 2.1.20).

32 Even more, animals empathise with lovelorn pastoral lovers and mourn their suicidal deaths which was given a special literary term: pastoral synaesia. Seeber calls it pastorale Synusie and defines it as "d[as] Motiv ... der ausdrücklichen Trauer der Natur um die Verstorbene.." [the motif of nature's explicit mourning for the deceased] [in this case, the heroine of a poem, SW] (Seeber 1979: 22). 
Arden is not a true locus amoenus. The practice and necessity to kill the indigenous animals of the Forest of Arden suggest disharmony traditionally excluded from the idyllic world. Precisely this aspect of the locale contributes much to the dual character of the forest in $A Y L I$ because it unfolds a new, threatening face of the place. Consequently, its image of the locus amoenus changes: it adopts the threatening features of locus horridus.

In this place a definition of locus horridus ${ }^{33}$ seems indispensable. It is, however, not an easy task. Even if the distinction between locus amoenus and locus horridus is clear-cut, the latter being the opposite of the former, ${ }^{34}$ the question of clearly defining the latter's nature is complicated. However, it seems easier as soon as one resorts to analysing utopian literature which employs the concept of both places, amoenus and horridus. ${ }^{35}$ If a utopian locus amoenus is a place where "man's dreams of a better world" come true ${ }^{36}$ locus horridus denotes a space where the worst nightmare becomes reality. ${ }^{37}$ Being a desolate, dark and hostile spot, not only does such a place give rise to horror and a feeling of fear in anybody who enters it, but it can pose a real danger to the new-comers' health and well-being. All those features which used to be considered advantageous in a locus amoenus become threatening in a locus horridus. A peaceful, solitary place of contemplation is now perceived as a desolate space where there is no one to help you out. Sympathetic inhabitants of the natural world become cruel beasts which can deprive you of your life. Trees which used to give pleasant shade in a locus amoenus now prevent anybody, even the sun, to enter the spot. The place is lonely, dark and cold.

33 The phrase is constituted by two Latin terms: locus 'a place' and horridus 'horrible' (cf. Plezia 1998, II: 729f.), s.v. horridus: "I.1.szorstki, nastroszony [rough, ruffled] I.2. ... przejmujący zimnem [piercingly cold]; II.1. straszliwy, okropny, budzący grozę (także świętą grozę) [horrible, terrible, awesome]".

34 Similarly, the same is true for another pairs of concepts: "Like the religious and the secular, utopia and anti-utopia are antithetical yet interdependent. They are 'contrast concepts', getting their meaning and significance from their mutual differences" (Kumar 1987: 100).

35 There is a subkind of utopian literature which is inspired by the tradition of Arcadia, its underlying point of reference (cf. Davis 1981: 22ff; see also Kumar 1987: 3ff).

36 Davis (1987: 12).

37 According to Stownik terminów literackich, the notion of locus horridus means "przeciwienstwo loci amoeni, literacki obraz miejsca przerażającego, przynoszącego człowiekowi udrękę, zagrażającego jego zdrowiu i życiu. W lit. epok dawnych rolę taką grały opisy czeluści podziemnych, puszcz i ostępów, a w lit. religijnej - piekła i czyśćca" [the opposite of loci amoeni, it is a literary representation of an awe-striking place bringing torment and threatening life and health of anyone who visits it. In the literature of the early ages the role was played by subterranean depths, primaeval forests and wilderness, and in religious literature - by the visions of hell and purgatory] (Głowiński et al. 1998: 287); s.v. locus horridus. 
Certainly, nobody will claim that the Forest of Arden is a typical example of a locus horridus. ${ }^{38}$ Still, there are some unusual traits about it which rather match the negative image and arouse ambiguous feelings in the audience. Consequently, the forest becomes an unconventional, ambivalent place, an idyllic one and a threatening one, and hence, the space of internal tensions.

Contrary to the generic conventions of the pastoral locus amoenus, the tensions depicted in AYLI not only represent the pastoral contrasts between the sophisticated and the ordinary way of life; against all expectations, the tensions also exist within the confines of the Forest of Arden, i.e. in the idyllic setting, traditionally devoid of struggle or strain. What is more, in the idiosyncratic locale of $A Y L I$ the threat is not only issued by people but also by the natural world. In the first place, the menace comes from animals which no longer empathise with troubled newcomers to the idyllic world but want to deprive them of their lives. In this context, it is enough to mention the lioness and the snake in Act IV, Scene 1, lying in wait for Oliver.

Constant, and therefore graver danger comes from the weather. Duke Senior describes the icy conditions in the forest:

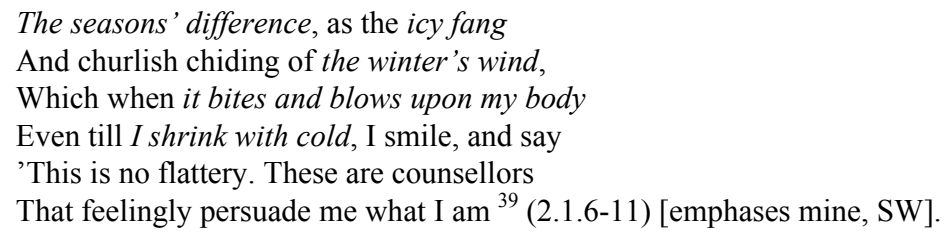

Even if Duke Senior extols the merits of life in humble conditions, it changes nothing for scholarly attentions: wrestling with imminent adversity within the confines of the locus amoenus is strange to the tradition of pastoral. The same concerns atmospheric conditions: as the convention holds it, the weather in the locus amoenus is fine and traditionally always favourable. It is a place of everlasting spring or summer; by no means has winter access to the pastoral world. ${ }^{40}$ In the passage quoted above, however, season change is not merely mentioned but it is focused upon. Winter is animated and portrayed as a dangerous animal: it "bites and blows upon my body". Thus, the alleged "counsellors" contradict the pastoral convention and become anti-pastoral elements in $A Y L I$. The quintessence of the pastoral and anti-pastoral allied in one sentence is given in the very next line of Duke Senior's oration: "Sweet are the uses of adversity"

\footnotetext{
38 Dystopian literature is full of loci horridi; a good example may be the forest in The handmaid's tale by Margaret Atwood.

39 The underlined words denote anti-pastoral loci.

$40 \quad$ "In Eden there was eternal summer" (AYLI 2001: 30, n. 5). The same concerns the Golden Age.
} 
(2.1.12). As already mentioned, the adjective "sweet" has its long-lasting pastoral connotation and, yet, it stands in stark contrast to the anti-pastoral "uses of adversity".

As the scene unfolds, the audience are acquainted with further details of the locale. Duke Senior's appraisal of the harsh realities of a forester's life is taken up by one of his companions, Amiens, who admits: "I would not change it [the life]. Happy is your Grace,/ That can translate the stubbornness of fortune/ Into so quiet and so sweet a style" (2.1.18-20) [emphases mine, SW]. Amiens voices a fairly pastoral standpoint acknowledging the superiority of the humble life to the one spent at court. He decides in favour of the new way of life that he "would not change". Further, he reinforces the pastoral overtone of the claim introducing classically pastoral adjectives to his speech: happy and sweet. It is worth noticing that the two words are stressed on the syntactic plane: the former comes at the very beginning and the latter at the end of the sentence. In such a way they gain special attention of the audience who are invited to the play on association. The happiness experienced in "so sweet a style" must evoke the remembrance of the locus amoenus.

There is still a greater surprise in store for the audience in the next utterance given by Duke: "Come, shall we go and kill us venison?/ And yet it irks me that the poor dappled fools,/ Being native burghers of this desert city,/ Should in their own confines with forked heads/ Have their round haunches gor'd (2.1.2124) [emphases mine, SW]. By now, the pastoral vision of the place has been reverted altogether: the Forest of Arden is no longer an idyllic refuge but, characterised as "the desert city", it has shown its dark side. It has changed out of all recognition becoming a locus horridus.

Not only does the place seem desolate and deserted ${ }^{41}$ but it seems a realm of injustice and cruelty. Even if Duke Senior takes pity on "the poor dappled fools", that have all right to inhabit the forest, he still wants to kill them in order to satisfy his needs. In this locale death takes a heavy toll on the native inhabitants that "have their round haunches gor'd" with arrows. Death is inflicted in an unequal fight between man and animal. Such a state of things is strange to the convention of the locus amoenus: neither empathy nor equality nor harmony nor peace is experienced in the Forest of Arden. All basic principles underlying pastoral are violated in the passage.

As the comedy unfolds, the audience are constantly confronted with unconventional features of the alleged locus amoenus. When the newcomers arrive at the boundaries of the forest, they are utterly exhausted: ${ }^{42}$

41 The Forest of Arden is called a desert many times in $A Y L I$, e.g. "in this desert place" (2.4.70); "in this desert" (2.7.17); "in this desert inaccessible" (2.7.110).

$42 \quad$ See also AYLI 2.4.1-2. 
More important than their extreme exhaustion is the fact that their spirits sink as they see the "uncouth forest". It seems to have terrified them. At its sight Orlando assumes that the forest is inhabited by wild beasts that pose danger to them. Moreover, he presupposes that the rule valid in the forest is the law of the jungle: either I kill you or you kill me. That the presupposition holds true as the time passes may well be proved by the fact that he advances Duke Senior's company "with sword drawn" (stage direction to 2.7). Having realised the inappropriateness of such behaviour, later on Orlando offers an excuse for it: "I thought that all things had been savage here" (2.7.107).

Violating the ethos of the conventional locus amoenus, the Forest of Arden proves "savage" towards the end of the play. Since $A Y L I$ is a comedy, the audience only vicariously assist cruel scenes: the dramatic events preceding the reconciliation between the brothers are related by Oliver. First, the spectators are shocked to see "this bloody napkin" (4.3.93). Only then are they told "how, and why, and where this handkerchief was stain'd" (4.3.96-97). It becomes clear that nobody is safe in the forest where wild beasts behave as insidiously as people: Oliver, sound asleep, almost gets bitten by "a green and gilded snake"; Orlando's arm is bleeding hurt by a lioness; ${ }^{44}$ successful hunters carelessly celebrate their victory over a deer killed in a hunt. ${ }^{45}$ The Forest of Arden is no longer harmonious and innocent, it has become a locus horridus.

The convention of the locus amoenus is not only played with, at times its value is put in question. It is the case with Jaques" mock version of "Under the

43 "Under an old oak, .../../ Lay sleeping on his back. About his neck/ A green and gilded snake had wreath'd itself,/ Who, with her head, nimble in threats, approach'd/ The opening of his mouth" (4.3.104-110). The scene evokes Edenic remembrances.

44 "... and here upon his arm/ The lioness had torn some flesh away,/ Which all this while had bled; and now he fainted" (4.3.146-148). Admittedly, the presence of a lioness in the English countryside is striking. Yet, “... the pastoral itself has a long tradition of being abstract and nonrealist, much more than concrete and realistic, for example perhaps most famously in Shakespeare's imaginary Forest of Arden in As You Like It, and it is thus not above being used as a setting to debate philosophical questions" (Barfield 2009: 165).

45 "It was in this way that the English pastoral became allied with singing huntsmen, sounding horns, and trophies of the chase, all quite improper to the Golden Age" (AYLI 2001: 102, $\mathrm{n}$. Scene 2). 
greenwood tree" (2.5. 46-54) where simplicity and innocence are major pastoral qualities subjected to his testing and derisive comments. In Jaques' opinion, anyone accepting the pastoral ethos of the place "turn[s] ass" (2.5.47) because "here [in the Forest of Arden] shall he see/gross fools as he" (2.5.52-53). Interestingly enough, the question of sound judgement of the locus amoenus is left open within the play. Admittedly, side by side with Duke Senior the characters often express their approval of the peaceful place. ${ }^{46}$ And yet one hears Touchstone claiming: "Ay, now am I in Arden, the more fool I; when I/ was at home I was in a better place, but travellers/ must be content" (2.4.13-15). What is more, notwithstanding the fact that Duke Senior as well as other courtiers praise the idyllic forest, all "dramatis personae" return to the court in the end. If actions count for more than mere words, the reading is clear: the pastoral world yields to the power of the outer world.

Yet, is the answer as simple as that? In fact, the question of the right evaluation of $A Y L I$ 's version of the pastoral world is as complicated as the one of its locus amoenus. Does the Forest of Arden pose a threat for the fugitives or does it offer them ultimate refuge from insoluble problems that they have to face at court? Actually, no final answer can be given. At times, the forest of Arden constitutes a peaceful, beautiful background for romantic adventures of its inhabitants. On this plane it is, indeed, a real locus amoenus. Yet, there is still another face of the locale: ${ }^{47}$ threatening as it at times appears, it can momentarily transform into a locus horridus where violence and injustice can be inflicted without any remorse or punishment. For one second, a dream becomes a nightmare.

The idiosyncrasy of the place evokes mixed feelings, even the more so with the Elizabethan audience who, taking delight in pastoral, must have been familiar with its generic conventions. Shakespeare's version of Arcadia poses a challenge. Still, the equivocally appealing forest is not constructed as a piece of art for art's sake. The unconventional features may have been accounted for: they aim at rendering the locus more real and, consequently, worthy of belief.

Shakespeare's treatment of death, a topic being major pillar of pastoral generic tradition, ${ }^{48}$ bears witness to such an explanation for non-typical traits of

46 Maybe the best praise of the locale is included in Amiens' song "Under the greenwood tree" $(2.5 \cdot 1-42)$

47 "Wyraźnie przedstawione są: dojmujący chłód, niebezpieczne zwierzęta (lwica), życiowa niedola (groźba utraty pracy przez Koryna), wreszcie ambiwalentny stosunek do natury, tak trafnie podkreślany przez sceptycznego Jakuba, według którego człowiek w lesie jest intruzem zakłócającym naturalny rytm przyrody" [There is a clear representation of: piercing cold, dangerous animals (lioness), adverse fortune (the threat of Corin losing his job), and finally an ambivalent attitude to nature, accurately stressed by sceptical Jaques, in whose opinion a man in the forest is an intruder disturbing the natural rhythm of nature.] (Gibińska et al. 2003: 92).

$48 \quad$ It had already been addressed in the Idylls by Theocritus: "Gewiss, die beiden fundamentalen Tragödien des menschlichen Daseins, enttäuschte Liebe und Tod, fehlen in Theokrits Idyllen ... 
the Forest of Arden. By convention, pastoral speakers often dwell upon sufferings of a forlorn lover who, like Daphnis, sometimes finds final consolation in suicidal death. ${ }^{49}$ Yet, challenging the tradition, Shakespeare only plays with it when Rosalind puts Orlando to silence retorting:

(Orl.[ando] Then in mine own person, I die.)

Ros.[alind] No, faith, die by attorney. The poor world is almost

six thousand years old, and in all this time there

was not any man died in his own person, videlicet,

in a love-cause. (...)

But these are all lies: men have died from

time to time and worms have eaten them, but not

for love

(4.1.89-103).

Undeniably, even if lacking all romanticism, the passage cannot be dismissed as unrealistic. Rosalynd's words mean cold shower on Orlando's inflamed heart. This exchange exemplifies Shakespeare's attitude towards tradition and his obedience to the rule of imitatio cum varatione. The variation means to him a compulsion to create literary pieces in which generic conventions are subordinate to the requirement of verisimilitude. ${ }^{50}$ Moreover, playing with the tradition Shakespeare wants to criticise its weak points. He succeeds in it, employing of the means of the satire; ${ }^{51}$ hence, the figure of Touchstone in AYLI. It is precisely him to play the telling role of a touchstone of the pastoral convention in the comedy. ${ }^{52}$

Throughout the play Shakespeare adopts a true-to-life perspective and, thus, he creates his own version of Arcadia. It is a beautiful, to some extent magic forest where everybody is invited to relax and enjoy the time spent in its con-

keineswegs". [Certainly, Theocritus' Idylls could not dispense with either of the fundamental tragedies of human existence, disappointed love and death.] (Panofsky 1996: 355). Theocritus set an example for generations of pastoral writers.

49 Theocritus invites the addressees to assist the lovers: his poems stand out from other pastorals due to the contemporaneity of the events (cf. for example, Idyll I and II, the latter unpastoral, though). Virgil, however, either anticipates or describes the death of the protagonists of his eclogues (cf. Panofsky 1996: 355f).

50 Concerning the clash between the idyllic and realistic view of the life in the Forest of Arden, see Bolewski 2002: 256f.

51 "[Satire] criticises, through ridicule and invective ... while pointing- usually implicitly but sometimes explicitly- to alternative and better ways of living" (Kumar 1987: 104).

Moreover, "Postacie Lakmusa i Anielki służą także krytyce konwencji sielankowej... Ich związek przeczy obrazowi wsi sielskiej i spokojnej. Lakmus wyśmiewa ten ideał w swych tyradach, a Anielka jest zaprzeczeniem typowej pasterki". [Both the characters, Touchstone and Audrey, are also employed to criticise the pastoral convention. Their relationship belies the ideal of a peaceful and idyllic countryside. Touchstone ridicules the ideal in his tirades and Audrey is a negation of a typical shepherdess] (Gibińska et al. 2003: 92).

52 Cf. Touchstone's role in AYLI, Act 3, Scene 2. 
fines; yet, the newcomers must fight against the adversities of nature as well as the dangerous fauna of the place just as in their real lives. Similarly to the indigenous inhabitants of the forest, the newcomers must earn their living hunting to stay alive. All these demanding and non-pastoral activities notwithstanding, they find their right place in the world because the locus amoenus helps them to discover their real natures and hidden desires. Fulfilling this ultimate task ascribed to the locus amoenus, the locale plays its traditional role.

\section{REFERENCES}

\section{PRIMARY SOURCES}

MacDonald, Hugh (ed.)

1962 England's Helicon. London: Routledge and Kegan.

Sannazaro, Jacopo

1948 L'Arcadia. ed. by Carrara Enrico. Torino: Unione Tipografico-Editrice Torinese. Shakespeare, William

2001 As you like it. The Arden edition of the works of William Shakespeare. Edited by Agnes Latham (ed.) London: Methuen.

\section{SECONDARY SOURCES}

Alpers, Paul

1996 What is pastoral? Chicago - London: University of Chicago Press.

Barfield, Steven

2009 "A full moon risen and the sheep gathered round him: Exploring Samuel Beckett's uncanny postpastoral", in: David James - Phillip Tew (eds.) New version of pastoral. post-Romantic, modern and contemporary responses to the tradition, 156-173.

Bloch, Ernst

1976 “Arkadien und Utopien”, in: Klaus Garber (ed.) Europäische Bukolik und Georgik, $1-7$.

Bolewski, Jacek SJ

2002 Objawienie Szekspira. Warszawa: Biblioteka "Więzi".

Chaudhuri, Sukanta

1989 Renaissance pastoral and its English developments. Oxford: Clarendon Press. Cooper, Helen

1977 Pastoral. Medieval into Renaissance. Rowman-Littlefield: D.S. Brewer.

Davis, J.C.

1981 Utopia and the ideal society. A study of English utopian writing 1516-1700. Cambridge: Cambridge University Press.

Garber, Klaus (ed.)

1976 Europäische Bukolik und Georgik. Darmstadt: Wissenschaftliche Buchgesellschaft. 
Gibińska, Marta - Marta Kapera - Jacek Fabiszak (eds.)

2003 Szekspir: leksykon. Kraków: Znak.

Głowiński, Michał - Teresa Kostakiewiczowa - Aleksandra Okopień-Sławińska - Janusz Sławiński (eds.)

1998 Stownik terminów literackich. Wrocław: Zakład Narodowy im. Ossolińskich.

James, David - Phillip Tew (eds.)

2009 New versions of pastoral. Post-Romantic, modern and contemporary responses to the tradition. Madison: Fairleigh Dickinson University Press.

Hunter, G.K.

1962 William Shakespeare: The late comedies. London: Longmans, Green.

Kumar, Krishan

1987 Utopia and anti-utopia in modern times. Oxford: Basil Blackwell.

Loughrey, Bryan (ed.)

1984 The pastoral mode. A casebook. London: Macmillan Publishers.

Mangan, Michael

1996 A preface to Shakespeare's comedies: 1594-1603. London: Longman.

Marinelli, Peter

1971 Pastoral. London: Methuen.

Panofsky, Erwin

1996 Sinn und Deutung in der bildenden Kunst. Köln: DuMont Buchverlag.

Plezia, Marian (ed.)

1998 Słownik Łacińsko-Polski. Warszawa: Wydawnictwo Naukowe PWN

Salingar, Leo

1974 Shakespeare and the traditions of comedy. Cambridge: Cambridge University Press.

Seeber, Hans-Urlich

1979 Moderne Pastoraldichtung in England. Studien zur Theorie und Praxis der pastoralen Versdichtung in England nach 1800 mit besonderer Berücksichtigung von Edward Thomas (1878-1917). Frankfurt am Main: Peter D. Lang.

Schmidt, Ernst A.

1972 Poetische Reflexion. Vergils Bukolik. München: Wilhelm Fink Verlag. Smith, Hallett

1966 Elizabethan poetry. A study in conventions, meaning, and expression. Cambridge: Harvard University Press.

Snell, Bruno

1976 “Arkadien. Die Entdeckung einer geistigen Landschaft”, in: Klaus Garber (ed.) EuroSnyder, Susan päische Bukolik und Georgik, 14-43.

1998 Pastoral process. Spenser, Marvell, Milton. Stanford: Stanford University Press. 